\title{
Penerapan Metode Blended Learning dalam Penerapan Pembelajaran Seni Budaya di SMA Negeri 9 Manado
}

\author{
${ }^{1}$ Frisilia L. Durikase, ${ }^{2}$ Jeane M. Tulung, ${ }^{3}$ Berehme A. Purba \\ Institut Agama Kristen Negeri Manado \\ ${ }^{1}$ frisiliadurikase420@gmail.com, ${ }^{2}$ jean.tulung@iakn-manado.ac.id, ${ }^{3}$ admopurba@yahoo.com
}

\begin{abstract}
Abstrak
Tujuan dari penelitian ini adalah untuk menjelaskan proses penerapan metode blended learning dalam pembelajaran seni budaya. Penelitian ini merupakan penelitian kualitatif dengan metode deskriptif yang dilaksanakan di SMA N 9 Manado pada tahun 2021.Data dikumpulkan melalui observasi, wawancara dan studi dokumentasi. Dari hasil analisis dan interpretasi data diperoleh indikasi bahwa: 1) Metode pembelajaran yang digunakan dari tiga orang guru mata pelajaran seni budaya pada saat pembelajaran daring dan luring berbedabeda. Adapun metode yang digunakan seperti metode ceramah, diskusi, discovery, tanya jawab belajar sambil memberikan contoh kepada siswa dengan bermain alat musik. 2) Proses penerapan metode blended learning dalam pembelajaran seni budaya didapati ada beberapa yang mengimplementasikan dalam pembelajaran seni budaya, dengan alasan bahwa pembelajaran seni musik khusus praktek harus adanya penggabungan pembelajaran secara daring dan luring karena pembelajaran daring hanya memiliki alokasi waktu yang sedikit dan terbatas sedangkan secara luring bisa melaksanakan praktek musik secara langsung. Dari hasil temuan tersebut maka direkomendasikan yang pertama bagi pihak pimpinan sekolah dan guru mata pelajaran agar mengadakan evaluasi dengan siswa selama pembelajaran daring berlangsung dengan melihat berbagai kendala yang dihadapi selama pembelajaran berlangsung. Kemudian bagi guru mata pelajaran agar lebih kreatif dalam mengembangkan metode pembelajaran dengan memanfaatkan IPTEK dan membuat konten-konten pembelajaran.
\end{abstract}

\section{Kata Kunci: Metode Pembelajaran, Blended Learning, Seni Budaya}

\begin{abstract}
The purpose of this study is to explain the process of applying the blended learning method in learning arts and culture. This research is a qualitative research with a descriptive method which was carried out at SMA N 9 Manado in 2021. Data were collected through observation, interviews and documentation studies. From the results of the analysis and interpretation of the data, there are indications that: 1) The learning methods used by the three teachers of arts and culture subjects during online and offline learning are different. The methods used are lecture, discussion, discovery, question and answer learning methods while giving examples to students by playing musical instruments. 2) The process of applying the blended learning method in learning arts and culture, it was found that there were some who implemented it in learning arts and culture, on the grounds that music learning specifically for practice must incorporate online and offline learning because online learning only has a small and limited time allocation, whereas online learning only has a small and limited time allocation. offline can carry out live music practice. From these findings, it is recommended that first the school leadership and subject teachers conduct evaluations with students during online learning by looking at the various obstacles faced during the learning process. Then for subject teachers to be more creative in developing learning methods by utilizing science and technology and creating learning content.
\end{abstract}

Keywords: Learning Methods, Blended Learning, Cultural Arts 


\section{Pendahuluan}

Corona Virus Disease atau biasa dikenal dengan COVID-19 pada akhir tahun 2019 mengejutkan dunia. Virus ini awalnya berasal dari kota Wuhan, China. World Health Organization (WHO) sebagai lembaga kesehatan dunia telah menetapkan covid-19 sebagai pandemi. ${ }^{1}$ Indonesia sendiri, kasus pertama ditemukan dua orang warga Indonesia domisili Depok. Dua warga tersebut memiliki riwayat interaksi dengan warga negara Jepang yang diketahui sudah terpapar virus covid-19. Adapun gejala yang dialami seperti batuk, pilek, sesak, bahkan demam. $^{2}$

Dampak pandemi covid-19 mempengaruhi hampir seluruh sektor di Indonesia bahkan dunia. Berbagai upaya telah dilakukan dunia untuk segera mengatasi pandemi covid-19. Pemerintah Indonesia sendiri juga turut membuat kebijakan untuk mengatasi pandemi covid-19 salah satunya melalui penerapan kebijakan pembatasan sosial berskala besar (PSBB). PSBB ini bertujuan untuk mengurangi dan memutus mata rantai penularan virus covid-19.

\footnotetext{
${ }^{1}$ Hermansyah Batin Mangku,et.al.,
} Covid19 \& Disrupsi Tatanan Sosial, Budaya, Ekonomi, Politik, dan Multi, (Lampung: Pusaka Media, 2020), h.84

${ }^{2}$ Administrator, Kasus COVID-19

Pertama Masyarakat Jangan Panik, https://indonesia.go.id/narasi/indonesia-dalamangka/ekonomi/kasus-Covid-19-pertamamasyarakat-jangan-panik (diakses 28 Maret 2021).
Sulawesi Utara sebagai salah satu provinsi di Indonesia yang memiliki kasus covid-19 turut serta melakukan penerapan kebijakan PSBB. Sejak diterapkannya PSBB, hampir semua aktivitas masyarakat menjadi berubah karena sebagian besar kegiatan harus dilakukan dari rumah atau istilahnya Work From Home. Penerapan kebijakan PSBB ini sangat berdampak hampir diseluruh sektor tak terkecuali pada sektor pendidikan khususnya dalam pembelajaran seni budaya (seni musik).

Dewasa ini, pendidikan merupakan suatu hal yang sangat penting bagi semua masyarakat, karena dengan adanya pendidikan bisa membentuk pribadi seseorang menjadi lebih baik. Pendidikan seni musik merupakan bentuk pembelajaran yang mengungkapkan ide atau gagasan dari seseorang yang didalamnya menggunakan unsur-unsur musik, sehingga menghasilkan karya musik yang tidak lepas dari nilai estetika. Seni musik biasanya mencakup kemampuan seseorang untuk menguasai olah vokal, memainkan alat musik serta mampu berkarya dan mengapresiasikan suatu karya musik. ${ }^{3}$

Adanya pendidikan dapat mengembangkan potensi yang ada pada

\footnotetext{
${ }^{3}$ Amelia Shifa Royani, Implementasi Kurikulum 2013 Dalam Pembelajaran SBK Khususnya Seni Musik di SD; https:www.academia.edu/7674630/Artikel_Pen didikan_Seni_Musik_Amelia_Shifa_Royani_4 B (diakses 28 Maret 2021)
} 
peserta didik sehingga tetap mampu memposisikan dirinya dalam setiap perubahan yang terjadi dalam kehidupan. Pandemi covid-19 membawa perubahan bagi dunia pendidikan termasuk pada proses pembelajaran. Proses pembelajaran biasanya dilakukan di dalam kelas secara tatap muka. Namun sejak adanya pandemi covid-19, maka pembelajaran berubah menjadi pembelajaran secara daring (dalam jaringan) melalui media seperti laptop, computer dan handphone.

Di tengah pandemi covid19, saat ini guru dan siswa harus diperhadapkan dengan situasi atau keadaan yang baru dan berbeda dari biasanya yang pastinya. Pembelajaran yang awalnya dilaksanakan secara tatap muka harus digantikan dengan pembelajaran secara online yang membuat guru dan siswa mau tidak mau harus memposisikan diri pada kondisi pandemi covid-19.

Hal tersebut juga dirasakan oleh seluruh warga SMA N 9 Manado, akibat pandemi pembelajaran harus secara daring dan memerlukan implementasi metode pembelajaran yang kreatif dari sorang guru kepada siswa. Namun pada kenyataannya pembelajaran daring khusus seni budaya materi praktek musik mendapat kendala disaat pembelajaran karena harus memerlukan pembelajaran secara luring untuk implementasi praktek musik karena terkadang secara daring sulit untuk melaksanakan pembelajaran praktek musik dari seorang guru terhadap siswa.

Akibat dari implementasi penggabungan pembelajaran secara daring dan luring sehingga adanya penerapan metode blended learning dalam pembelajaran seni budaya. Hal tersebut dilakukan karena perlu adanya monitoring langsung dari guru mata pelajaran terhadap tugas yang diberikan dan mengajarkan secara langsung kepada murid, dan dalam pembelajaran secara daring, penerapan metode pembelajaran memang sangat terbatas akibat pandemi dan tidak bisa dipungkiri pemanfaatan IPTEK dalam pembelajaran juga masih minim di gunakan seperti contoh pembuatan konten-konten pembelajaran oleh guru mata pembelajaran, sehingga penyampaian materi secara daring terkadang mengalami kendala dan mengambil inisiatif untuk pembelajaran secara luring.

Akibat penggabungan antara pembelajaran secara online dan offline atau penerapan metode blended learning dilaksanakan guru serta siswa merasa lebih efektif dalam pelaksanaan pembelajaran, disamping materi yang tersampaikan dengan baik adapula interaksi secara tatap muka yang bisa didapatkan antara guru dan siswa serta siswa ke siswa. Berdasarkan hal tersebut maka peneliti ingin mencari tahu bagaimana metode pembelajaran yang 
digunakan oleh guru seni budaya pada masa pandemic, dan bagaimana proses pembelajaran blended learning di SMA Negeri 9 Manado

\section{Metode}

Penelitian ini mengunakan metode kualitatif dengan pendekatan studi kasus, data-data yang digunakan dengan memanfaatkan data dari hasil observasi, wawancara dan studi dokumentasi di tempat penelitian untuk melihat fenomena yang terjadi di lokasi penelitian lebih khusus dalam penerapan metode pembelajaran yang digunakan oleh guru mata pelajaran seni budaya serta proses penerapan metode blended learning dalam pembelajaran seni budaya.

\section{Hasil dan Pembahasan}

Adapun hasil penelitian ini merupakan analisis data yang sudah diperoleh melalui observasi, wawancara serta studi dokumentasi yang dilakukan oleh peneliti di lokasi penelitian yaitu SMA N 9 Manado. Hasil observasi yang peneliti dapatkan diantaranya yaitu: selama masa pandemi covid-19 SMA N 9 Manado telah menerapkan pembelajaran daring dengan media yang digunakan adalah aplikasi khusus meeting yaitu Microsoft Teams, aplikasi ini bisa diakses melalui play store dalam smartphone dan bisa di aplikasikan melalui handphone, labtob, dan computer. Selama pembelajaran berlangsung yang dilakukan guru dan siswa operator sekolah bisa memonitoring proses belajar mengajar yang dilakukan.

Dalam melakukan observasi pada pembelajaran seni budaya di SMA N 9 Manado terdapat beberapa metode pembelajaran yang digunakan guru untuk menyampaikan materi pembelajaran, ada yang memberikan materi dengan metode ceramah kemudian memberikan contoh dengan bantuan alat musik seperti gitar, adapun yang memberikan materi melalui video pembelajaran yang diperoleh dari internet atau membuat langsung, dan ada yang memberikan materi dengan menjelaskan kepada siswa kemudian memberikan contoh melalui vokal atau dinyanyikan. Dari hasil observasi juga didapati bahwa penggunaan RPP dan silabus disesuaikan pada masa pandemi covid-19 terutama pada alokasi waktu pembelajaran yaitu hanya 30 menit dan jika lebih dari 30 menit itu hanya untuk materi presentasi kelompok.

Selama melakukan observasi tidak semua guru dan siswa melakukan pembelajaran secara daring sesuai himbauan pihak sekolah, namun ada beberapa yang melaksanakan secara offline atau secara langsung. Dalam melakukan observasi peneliti mendapatkan adanya alasan-alasan tertentu yang membuat beberapa guru serta siswa melakukan pembelajaran secara offline dan beberapa siswa lebih tertarik pembelajaran secara langsung karena materi yang disampaikan lebih 
mudah dipahami dan dimengerti dibandingkan dengan pemberian materi secara daring, pembelajaran secara daring membuat siswa kurang memahami materi yang disampaikan, serta timbul rasa bosan yang mengakibatkan pembelajaran tidak tersampaikan dengan baik. Dapat dilihat bahwa dengan menggabungkan metode pembelajaran secara daring atau online dengan pembelajaran secara langsung atau offlline siswa lebih tertarik dan merasa lebih efektif dalam melaksanakan proses pembelajaran.

Adapun proses pembelajaran secara daring dan luring oleh siswa SMA N 9 dalam pembelajaran seni budaya yaitu Dalam pembelajaran seni budaya secara online atau daring di SMA N 9 Manado guru dan siswa melaksanakan pembelajaran melalui ruang virtual dengan menggunakan aplikasi khusus meeting yaitu Microsoft Teams. Dalam penggunaan aplikasi ini dapat memudahkan guru serta siswa dalam pembelajaran secara online pada kondisi pandemi saat ini, karena aplikasi ini memiliki kelebihan-kelebihan yang dapat membantu memudahkan pembelajaran secara jarak jauh. Selain kelebihannya sebagai media pembelajaran jarak jauh, dalam aplikasi ini pun guru bisa dengan mudah melakukan penilaian hasil dari ujian siswa juga bisa sampai pada tahap evaluasi dari hasil kerja siswa. Dalam pembelajaran seni budaya secara online guru mata pelajaran menggunakan beberapa metode pembelajaran yang diimplementasikan untuk mencapai tujuan pembelajaran. Berdasarkan teori yang ada yang berkaitan dengan metode pembelajaran dikatakan bahwa "metode pembelajaran merupakan sebuah strategi atau taktik dalam melaksanakan kegiatan belajar mengajar di dalam kelas yang diaplikasi tenaga pendidik agat tujuan pembelajaran yang sudah ditetapkan bisa tercapai dengan baik" ${ }^{4}$ Adapun proses penyampaian materi yang diberikan oleh guru kepada siswa yaitu dengan mempresentasikan melalui power point, memberikan vidio pembelajaran yang dibuat sendiri ataupun yang diambil melalui internet. Adapun proses pembelajaran secara offline dilakukan dengan tetap mematuhi protokol kesehatan, dimana guru memonitoring langsung siswa dalam pembuatan tugas dan penilaian secara langsung serta siswa membuat tugas. Aktivitas yang dilakukan adalah guru datang langsung ke kelompok belajar siswa yang telah dibentuk dan pengelompokan tersebut berdasarkan jarak tempat tinggal siswa yang berdekatan, waktu guru memonitoring siswa untuk mata pelajaran praktek musik adalah diluar jam pelajaran, kemudian guru memonitoring pembelajaran praktek

\footnotetext{
${ }^{4}$ M. Prawiro, Metode Pembelajaran: Pengertian, Macam-macam, Fungsi, dan Tujuannya, https://www.maxmanroe.com/vid/umum/metod e-pembelajaran.html (diakses 29 Juni 2021)
} 
musik dengan mengajarkan materi praktek khusus musik kreasi baru. Sedangkan materi untuk memainkan alat musik barat, guru melihat proses pembelajaran siswa dalam memainkan alat musik barat.

\section{Kesimpulan}

Berdasarkan hasil penelitian yang membahas penerapan metode blended learning dalam pembelajaran seni budaya di SMA N 9 Manado, dapat disimpulkan bahwa:

1. Metode pembelajaran yang diterapkan oleh masing-masing guru seni budaya di SMA N 9 Manado pada saat pembelajaran daring ada beberapa metode seperti metode ceramah, metode discovery, mengajar sambil memberi contoh dengan alat musik dan mengajar sambil memberi contoh dengan bernyanyi. Dari beberapa metode tersebut yang diterapkan dalam pembelajaran ada siswa yang merasa senang dengan terapan metode pembelajaran yang diberikan dan adapula yang mengalami kendala dalam pembelajaran berlangsung seperti kurang memahami materi pembelajaran yang disampaikan, serta kurang adanya evaluasi dari guru terhadap siswa mengenai apa yang menjadi kendala selama pembelajaran.

Penerapan

multimetode dari seorang guru seni budaya sangat dibutuhkan selama pembelajaran agar mampu menarik minat belajar siswa dan menghilangkan rasa bosan dari siswa, sehingga tujuan pembelajaran bisa tercapai dengan baik. Pemanfaatan teknologi dalam pembelajaran juga sangat diperlukan oleh guru karena selain materi tersampaikan dengan baik namun juga bisa menarik minat belajar siswa.

2. Proses penerapan metode blended learning dalam pembelajaran seni budaya di SMA N 9 Manado didapat hanya beberapa yang menerapkan seperti dari tiga orang guru seni budaya hanya ada satu yang menggabungkan pembelajaran online dan offline karena adanya materi praktek musik yang harus diajarkan langsung dan dikontrol langsung oleh guru tersebut seperti saat bermain alat musik serta bisa melakukan penilaian secara langsung sedangkan dua orang guru lainnya belum menerapkan gabungan pembelajaran online dan offline meskipun berdasarkan pendapat keduanya bahwa untuk pembelajaran seni budaya khusus praktek musik harus adanya pertemuan 
secara langsung mengingat ada praktek musik yang harus dicontohkan langsung kepada peserta didik, dan siswa yang melaksanakan pembelajaran secara offline merasa lebih efektif dalam pembuatan tugas musik kontemporer secara langsung.

\section{Kepustakaan}

Administrator, Kasus Covid-19 Pertama Masyarakat Jangan Panik, http://indonesia.go.id/narasi/indonesi a-dalam-angka/ekonomi/kasuscovid-19-pertama-masyarakatjangan-panik (diakses 28 Maret 2021, pukul 19.30 WITA)

Black James A \& Champion Dean J, Metode \& Masalah Penelitian Sosial, Bandung: PT. Refika Aditama, 2009

Darmadi Hamid, Metode Penelitian Pendidikan, Pontianak: Alfabeta, 2011

Ermayulis Syafni, Penerapan Sistem Pembelajaran Daring dan Luring di Tengah Pandemi Covid-19, https : www . stit - alkifayahriau . ac . id / penerapan - sistem - pembelajaran - daring - dan - luring - di tengah pandemi- covid - 19/ (diakses 18 Maret 2021, pukul 20.40 WITA)

Handarini Oktafia Ika \& Wulandari Siti Sri, Pembelajaran Daring Sebagian Upaya Study From Home (SFH) Selama PandemiCovid-19, http://journal.unesa.ac.id/indeks.php ljpap (diakses 18 Maret 2021 pukul 21.15 WITA)

Kasiram H.Moh, Metodologi Penelitian Kualitatif -Kuantitatif, Malang: UIN_Maliki Press, 2010
Mangku Hermansyah Batin, et.al., Covid19 \& Disrupsi Tatanan Sosial Budaya Ekonomi, Politik dan Multi, Lampung: Pusaka Media, 2020

Milianti Ajeng Ayu, Studi Literatur Studi Dokumentasi, https://textid.123dok.com/document/1y931r8rystudi-literatur-studidokumentasi.html, (diakses $07 \mathrm{Juli}$ 2021 pukul 09.30 WITA)

Mulyana Aina, Model Pembelajaran Discovey Learning Atau Penemuan, https://ainamulyana.blogspot.com/2 016/06.model-pembelajarandiscovery-learning.html (diakses 26 Juli 2021 pukul 13.00 WITA)

Nainggolan Alon Mandimpu, Blended Learning Sebagai Model Pembelajaran Pendidikan Agama Kristen Di Pendidikan Tinggi Pada Masa Dan Pasca Pandemi Covid19, (diakses 15 April 2021 pukul 19.15 WITA)

Pengertian Seni Budaya, Macam, Fungsi, dan Contohnya, https://dosensosiologi.com/senibudaya/ (diakses 18 Maret 2021 pukul 22.00 WITA)

Prawiro M, Metode Pembelajaran: Pengertian, Macam-macam, Fungsi, dan Tujuannya, https://www.maxmanroe.com/vid/um um/metode-pembelajaran.html (diakses 29 Juni 2021 pukul 15.30 WITA)

Purnama Medina Nur Asyifah, Blended Learning Sebagai Sarana Optimalisasi Pembelajaran Daring di Era New Normal; (September 2020)

Rahman Pispian, Konsep, Manfaat dan Karakteristik Pelajaran Seni Budaya, https://pispianrahman.wordpress.co m/2016/12/05/\%e2\%80\%8bkonsepmanfaat-dan-karakteristik-pelajaranseni-budaya/ (diakses 05 Mei 2021 pukul 20.30 WITA) 
Rezkia Salsabila Miftah., Langkahlangkah Menggunakan Teknik Analisis Data Kualitatif, https;//www.dqlab.id/data-analisispahami-teknik-pengumpulan-data (diakses 19 Maret 2021 pukul 19.00 WITA)

Royani Amelia Shifa, Implementasi Kurikulum $2013 \quad$ Dalam Pembelajaran SBK Khususnya Seni Musik di $S D_{2}$ https:www.academia.edu/7674630/ Artikel Pendidikan Seni Musik Am elia Shifa Royani 4B (diakses 28 Maret 2021 pukul 17.45 WITA)

Setiawan Samhis., Pengertian Analisis Data- Tujuan, Prosedur, Jenis, Kuantitatif, Kualitatif, Para Ahli, https://www.gurupendidikan.co.id/ pengertian-analisis-data/ (diakses 19 Maret 2021 pukul 17.45 WITA).

Supriadie Didi \& Darmawan Deni, Komunikasi Pembelajaran, Bandung: PT Remaja Rosdakarya, 2012.

Sidiq Muhassar, Konsep Pendidikan Seni, https://www.academia.edu/3850859 9/Konsep-pendidikan-seni (diakses 28 Juli 2021 pukul 17.15 WITA)

Syaputri Kurnia, Model Pembelajaran Metode Ceramah, https://www.academia.edu/4321966 9/makalah-model-pembelajaranmetode-ceramah (diakses 26 Juli 2021 pukul 15.05 WITA)

Thabroni Gamal, Metode Pembelajaran: Pengertian, Jenis, \& Macam (Menurut Para Ahli) https://serupa.id/metodepembelajaran-pengertian-jenismacam-menurut-para-ahli/ (diakses 17 Maret 2021 pukul 22.00 WITA)

Waedana I Putu Mahendra Adi,et.al, Metode Tanya Jawab Dalam Pembelajaran, https://www.academia.edu/5297858/ Metode-tanya-jawab-dalam- pembelajaran (diakses 28 Juli 2021 pukul 14.00 WITA)

Widiara I Ketut, Blended Learning Sebagai Alternatif Pembelajaran di Era Digital, https://www.google.com/268199blended-learning-sebagai-alternatifpembelajaran-073a6660 (diakses 16 Maret 2021 pukul 21.40 WITA) 